REFLEXIÓN

Recibido: 29/10/2013

Revisado: 29/11/2013

Aprobado: 29/12/2013

\title{
MANUEL CANUTO RESTREPO, OBISPO DE PASTO (1870-1881) SU VISIÓN SOBRE EL CLERO Y EL LIBERALISMO EN COLOMBIA: EL CORDERO Y EL LOBO
}

\author{
GERMAN RODRIGO ROSALES ARTEAGA \\ Magíster en Historia \\ Universidad del Valle
}

"La historia fuera de anhelar entender el mundo, el universal, el de la patria, lo desea para el nuestro, el inmediato, el local, a fin de sentirnos más unidos a la grandeza de la nación"

Otto Morales Benítez ${ }^{1}$

\section{RESUMEN}

El Obispo Manuel Canuto Restrepo y Villegas (1825-1891), gobernó la diócesis de Pasto durante la década de los setentas del siglo decimonónico, un periodo de auge del proyecto político liberal radical, calificado por la historiografía de progresista, propio de una época de transformaciones e independencias, influenciado bajo la corriente de pensamiento llamada liberalismo, que buscaba una sociedad moderna laicizada, pero que veía en la Iglesia Católica, como su principal contradictor. En efecto, el prelado Restrepo, de rigurosa formación teológica, talante beligerante y acolitado por un pueblo pastuso tradicionalmente sumiso a los designios del clero le permitió desarrollar con mayor autonomía su fanática labor misional, hasta el punto de convertirse en el ideólogo más connotado e incendiario de la Iglesia por sus ataques al liberalismo y a la educación laica de los Estados Unidos de Colombia. Desde la clandestinidad de su destierro escribe una obra titulada, El Clero y el liberalismo en Colombia, motivo de análisis para el presente trabajo, en él expone su pensamiento político sobre la separación de la Iglesia y el Estado, resalta el aporte del clero a la República en la conformación de su nacionalidad, cuestiona los partidos políticos, condena los males contemporáneos como el liberalismo, el protestantismo y el comunismo, analiza algunos artículos de la Constitución de 1863, responsabiliza a los liberales como promotores de las guerras civiles en Colombia, asevera la inconstitucionalidad del destierro y termina victimizando al clero.

Palabras Clave: Clero, Liberalismo.

\section{ABSTRACT}

Bishop Manuel Canuto Restrepo y Villegas (1825-1891), governed the diocese of Pasto during the nineteen-seventies, a boom period of the radical liberal political project,

1. MORALES BENÍTEZ, Otto, Trascendencia, dimensión y proyección de las historias regionales y locales, México, Universidad Nacional Autónoma de México, 1993. p. 37. 
characterized by the historiography of progressive, typical of a time of Transformations and independence, influenced by the current of thought called liberalism, which sought a modernized society, but which saw in the Catholic Church as its main contradictor. The prelate Restrepo, with a rigorous theological formation, a belligerent and hospitable attitude by a Ptolemaic people traditionally submissive to the clergy's plans, enabled him to develop his fanatical missionary work with greater autonomy, to the point of becoming the most connotated and incendiary ideologue Of the Church for its attacks on liberalism and secular education in the United States of Colombia. From the clandestinity of his exile, he writes a work titled, The Clergy and Liberalism in Colombia, which is the subject of analysis for the present work, in which he expounds his political thought on the separation of Church and State, emphasizes the contribution of the clergy to Republic in the conformation of its nationality, questions political parties, condemns contemporary evils such as liberalism, Protestantism and communism, analyzes some articles of the Constitution of 1863 , blames the liberals as promoters of civil wars in Colombia, asserts The unconstitutionality of the exile and ends up victimizing the clergy.

Key Words: Clergy, Liberalism.

La Iglesia Católica en general y su institución eclesiástica ${ }^{2}$ se han convertido en variables analíticas para acercarnos al pasado, máxime en una región catalogada como tradicionalmente católica en dónde la figura del sacerdote ejerció poder y control social mediante la oratoria sagrada en un pueblo mayoritariamente analfabeta, por tanto, el sacerdote católico se convirtió en: "[...] el principal y con frecuencia el único agente político de la vida aldeana; [...] fue imprescindible en la comunicación política de las aspiraciones aldeanas y de las intenciones de la clase dirigente"3. Además de la

2. El historiador José David Cortés Guerrero, propone clarificar términos que usualmente se usan indistintamente como sinónimos, pero que se requiere precisarlos así: Institución eclesiástica responsable del apostolado y la misión, encargada de administrar lo sagrado; encabezada por el Pontífice, pasando por el colegio de obispos, y las autoridades de las comunidades religiosas los cuales conforman la jerarquía eclesiástica. Iglesia Católica, o simplemente Iglesia, se refiere a la comunidad de creyentes católicos, pero también incluida la institución eclesiástica con su jerarquía, Laicado o laico, hace alusión a los adherentes del credo católico que no hacen parte de la institución eclesiástica ni de su jerarquía. CORTÉS GUERRERO, José David. Curas y políticos: mentalidad religiosa e intransigencia en la diócesis de Tunja, Bogotá, Ministerio de Cultura, 1998, pp. 19-20.

3. LOAIZA CANO, Gilberto. Sociabilidad, religión y política en la definición de la Nación, Colombia 18201886, Bogotá, Universidad Externado de Colombia, 2011. p. 34. dimensión política, el cura para el pueblo significaba su orientador, su protector, su amigo; también lo solicitaban para que arregle sus conflictos y avive sus esperanzas ${ }^{4}$. Hasta los mismos liberales como Manuel Ancízar, reconocían el papel destacado atribuido al sacerdote en la labor "civilizadora" de los pueblos, llegando inclusive a asignarle la mayor parte de responsabilidad socio-cultural $\mathrm{y}$ hasta económica de los pueblos 5 . Veamos a continuación las concepciones del Obispo Restrepo, fiel representante de la corriente católica tradicionalista e intransigente en los diferentes ámbitos de debate del momento, plasmados en su obra "El clero y el liberalismo en Colombia", publicado en el Ecuador en julio de 1878 . En cuanto a la escritura, se recurrió especialmente para el caso de las fuentes primarias a la cita textual, para indicar el discurso tal cual fue plas-

4. LONDOÑO VEGA, Patricia, Religión, cultura y sociedad en Colombia, Medellín y Antioquía, 1850-1930, Bogotá, Fondo de Cultura Económica, 2004, p. 149.

5. PLATA QUEZADA, William "La romanización de la Iglesia en el siglo XIX, proyecto globalizador del tradicionalismo católico" contenido en: Globalización y diversidad religiosa en Colombia, Bogotá, Unibiblos, 2005 [Online] [Consultado 01 de octubre de 2013]. Disponible en http://www.bdigital.unal.edu. co/1390/4/03CAPI02.pdf , p. 123. 
mado por los autores, con toda su carga valorativa.

Iglesia vs. Liberalismo: una constante histórica.- Para el obispo Restrepo, la persecución que el liberalismo hizo a la Iglesia y su clero ${ }^{6}$ se remonta a la infancia de la Iglesia, hace remembranza de su institución como víctima de los ataques de liberalismo pagano y demostrando gala de su conocimiento en historia antigua escribe:

[...] basta haber recorrido brevemente las valientes y luminosas apologías de San Dionicio Obispo de Antioquía, de Atenágoras, de Minucio Féliz y las de Orígenes contra Celso, y Tertuliano contra Marcio, para ver en ellas, que entonces se hacían al Clero y á los cristianos las mismas acusaciones y calumnias que se les hacen hoy, [...] Todas estas infamias y calumnias eran el único proceso en que se apoyaban los tiranos de entonces para decretar la persecución, el destierro, la confiscación, el tormento y la muerte de los cristianos y sus ministros ${ }^{7}$.

En el contexto colombiano cree ver la génesis del liberalismo desde el momento mismo de las luchas emancipatorias, cuando el liberalismo comenzaba a "desenvolverse como una serpiente al pie del árbol de la libertad," y a la nación encantada por este discurso la representa con la débil Eva. Deja ver su admiración por

6. El estudio de fenómenos religiosos en Colombia a partir de la historia no es tarea fácil porque se traen los estigmas de la historia apologética, elaborada bajo la visión clerical de los miembros de la institución eclesiástica,[como es la del obispo Restrepo] o también el de la visión liberalizante que mostró y aún sigue mostrando todo lo relacionado con el campo religioso como algo contrario a la razón, digno de no ser estudiado, pues al hacerlo se caería en la defensa de una institución como la Iglesia Católica que le ha hecho -según esta visión- mucho daño al desarrollo del país; una historia equilibrada aún está por realizarse, CORTÉS GUERRERO, José David. Curas y políticos: mentalidad religiosa e intransigencia en la diócesis de Tunja, Op. Cit, p. 13.

7. RESTREPO, Manuel Canuto. "El clero y el liberalismo en Colombia", Folleto, Ecuador, julio de 1878. texto ubicado en la Biblioteca Museo Juan Lorenzo Lucero de Pasto, pp. 33-34;
Bolívar y condena la guerra secreta en su contra, refiriéndose, muy probablemente, a la Sociedad filológica Bogotana de 1828, en la cual se ideó la conspiración contra Bolívar:

[...] mientras que el Gran Bolívar, repetimos, paseaba en triunfo los pendones de la libertad y de la gloria nacional, desde los pantanos de Venezuela y las solitarias selvas del Orinoco, hasta las argentadas cumbres de Potosí, algunos sujetos en Bogotá se ocupaban en hacer una guerra secreta y terrible al Libertador, más que al rey Fernando VII, y preparaban un trono para mil tiranos y mil tiranías; [...] Hé aquí el liberalismo que comenzaba á desenvolverse cautelosamente, como una serpiente, al pie del árbol de la libertad; y la nación, cual otra Eva, encantada con la melodía de las palabras de aquel insidioso reptil, $[\ldots]^{8}$

El Clero y el pueblo católico fundaron la República.- El obispo Restrepo, con la vehemencia que lo caracterizaba, reclamaba mejor trato al estamento "clerical abnegado" por el servicio dado a la patria desde sus orígenes; para él, el clero entregó su talento y la Iglesia su ministerio e influencia al servicio del triunfo republicano, de lo contrario esta causa habría fracasado; defendía a la Iglesia como un modelo de unidad nacional, como una institución civilizadora, perseguida por el liberalismo":

El Clero y el pueblo católico fundaron la república independiente sobre las bases del Catolicismo; el uno con sus talentos,

8. Ibíd., p. 2.

9. La historiografía confesional, ha sido la encargada de recoger esta interpretaciones en efecto, contraponer las últimas décadas coloniales a las desdichas posteriores a la revolución, denunciando al mismo tiempo la injusticia de que un clero que había sido importante o incluso decisivo para su positiva resolución -al menos para el logro de la independencia política- fuera retribuido con la imposición de intolerables vejámenes. Véase: DI STEFANO, Roberto, "El púlpito y la plaza: clero, sociedad y política de la monarquía católica a la república rosista" primera edición, Buenos Aires, Siglo XXI Editores Argentina, 2004, p. 127. 
riquezas y prestigio, y el otro con sus fatigas y su sangre. Todos llevaron sus ofrendas al altar común de los sacrificios por la libertad, y la patria se salvó; y sin embargo hoy se levantan voces liberales para afirmar que el Catolicismo y la república son incompatibles. iQué monstruoso absurdo! El Catolicismo, ó sea la Religión Católica, no es incompatible con ningún sistema de gobierno y mucho menos con el republicano; porque el Catolicismo es la Religión popular por excelencia y sus más elevados puestos están al alcance de todos ${ }^{10}$.

Sin embargo, el obispo parecía olvidar que la actuación de la Iglesia frente a la Independencia fue diversa entre la jerarquía y el bajo clero; los pertenecientes al alto clero por ejemplo, los prelados que eran españoles y criollos debían obediencia al patronato, en consecuencia la gran mayoría apoyaban la causa realista ${ }^{11}$; Por su parte en el resto del virreinato la generalidad bajo clero conformado por sacerdotes, presbíteros y monjes misioneros que desarrollaban su labor en parroquias pequeñas, pueblos y aldeas, estaba compuesto étnicamente por criollos de bajo rango y mestizos, y fueron partidarios en mayor porcentaje que los prelados por la causa patriota. Para mayor ilustración se encuentra el caso del obispo de Popayán, Salvador Jiménez de Enciso, quien gobernaba eclesiásticamente el sur de la República y era un defensor a ultranza del monarca Fernando VII, pero: "Después del triunfo de Sucre en Pichincha ( 24 de mayo de 1822), adopta una posición patriota ante la emancipación americana y escribe a Pío VII justificando su propia conducta y exaltando las virtudes y benevolencia del Libertador"12. De igual forma, el

10. RESTREPO, Manuel Canuto, "El clero y el liberalismo en Colombia", Op. Cit., p. 3.

11. Martínez de Codes. Rosa María, La Iglesia Católica en la América Independiente, Madrid (Siglo XIX). Editorial MAPFRE, 1992, p. 61.

12. Ibíd., p. 66. erudito prelado Restrepo parecía olvidar o ignorar que la Iglesia católica durante el largo periodo feudal para Europa y periodo colonial para América vivió en contubernio con los gobiernos, hasta el punto que la jerarquía católica llegó a enquistar también el poder político, ejemplo de esto fue el caso del ilustrado español Antonio Caballero y Góngora.

Las revoluciones las ha hecho el liberalismo, la Iglesia y el clero han sido sus víctimas ${ }^{13}$.- Restrepo, fiel representante y defensor incansable de la Iglesia católica, responsabilizó al partido liberal colombiano como el promotor de las guerras civiles en Colombia desde la "Guerra de los Supremos" (1839-1842), hasta la guerra de "Los Obispos" (18761877) para cada una de manera hábil buscó argumentos y eximió todo tipo de responsabilidad al clero, veamos:

¿Quién se rebeló en el año de 1840 contra el gobierno legítimo e inundó en lágrimas y sangre la Nueva Granada? Fue el partido liberal el autor único de aquellas escenas de barbarie y de muerte, y sin embargo llama rebelde al Clero. ¿Fue el Clero o por su consejo y con su ayuda, que los democráticos de Bogotá rodearon al Congreso del año de 49 para obligarlo con la libertad del puñal á que eligiesen presidente de la república al general López, más bien que a otro candidato? No. Fue el partido liberal. ¿Fue el Clero o por su consejo y con su ayuda, que los generales Obando y Melo el 17 de abril del año de 54, proclamaron una dictadura de cuartel, disolvieron el Congreso de la nación y llenaron de calamidades y de sangre la

13. Entre 1825 y 1869, la Iglesia americana, así como la sociedad, se encuentran atrapadas entre dos proyectos contradictorios: el de la restauración y el de la secularización; la crisis se agrava tanto para el Estado como para la Iglesia. Los liberales desarrollan entonces una ofensiva. Véase en: MARTÍNEZ DE CODES. Rosa María, Op. Cit., p. 168. 
república? No. Esa fue obra exclusiva del partido liberal ${ }^{14}$.

El historiador Fernán González, en su obra Partidos, guerras e Iglesia en la construcción del Estado Nación en Colombia 1830-1900, al tipificar las tres primeras guerras del siglo decimonónico, reconoce que en la polémica siempre estuvo presente el papel de la iglesia en la sociedad; ${ }^{15}$ el mismo Canuto Restrepo en la Guerra civil de 1851 tomó las armas y protagonizó el impase de los fusiles ${ }^{16}$. La guerra de 1876-1877, más conocida por la historiografía colombiana como "Guerra de las Escuelas", motivada ante la reforma educativa de 1870 , desencadenó un nuevo conflicto con la jerarquía de obispos ultramontanos en torno al carácter laico o católico de la educación pública. Su habilidad en la argumentación está en citar ideólogos dedicados a defender el catolicismo en el país como José Manuel Groot y José María Samper:

En el año de 1875, el Sor. Dor. Santiago Pérez vio que se acercaba el fin de los días de su vida presidencial, y sin hacer caso de la República, de la autonomía de los Estados y con poco respeto á la Constitución, quiso darse un sucesor á su antojo [...] Después de escándalos, atropellos y encarcelamiento de ciudadanos distinguidos, como el republicano y valiente escritor Sor. Dor. José María

14. RESTREPO, Manuel Canuto, "El clero y el liberalismo en Colombia", Op. Cit., p. 4.

15. GONZÁLEZ GONZÁLEZ, Fernán E. "Partidos, guerras e Iglesia en la construcción del Estado Nación en Colombia (1830-1890)", Medellín, La Carreta Editores, 2006, pp. 15-68.

16. El joven sacerdote Restrepo, en Abejorral -su tierra natal- fue protagonista en la asonada para quitar los 700 fusiles que en junio venían desde Sonsón hacía esta ciudad, combatió junto con los generales conservadores Eusebio Borrero y Braulio Henao; quienes terminada la confrontación con resultados adversos para su partido y para la iglesia, prefirieron entregarse y en un manifiesto fechado en septiembre de 1851, el general Henao responsabilizó a Restrepo como el causante de la revolución y el impase de los fusiles. Amplíese en: ORTIZ MESA, Luis Javier, "Obispos, clérigos y fieles en pie de guerra Antioquia, 1870-1880", Op. Cit., pp. 200-210.
Samper, envió la guardia colombiana armada y racionada con las armas y el dinero de la nación, á los Estados del Atlántico para quitar y poner gobiernos á su modo; preparar elecciones, inquietar á los pueblos, provocarlos á la revolución; lanzarlos en la guerra [...]

El señor doctor Salvador Camacho Roldan, [...] en la Cámara de Representantes, [...] concluye: "la verdad histórica exige que se reconozca y proclame que la persecución, el destierro, el martirio de los herejes fueron ejecutados por el brazo de hierro del poder temporal, nó por la espada espiritual de los Papas y de los Obispos"17.

Otra estrategia para responsabilizar al gobierno como promotor de la guerra fue el utilizar algunos fragmentos de los mismos liberales y usarlos a su favor:

El Señor doctor Eustorjio Salgar ha dicho en una pieza oficial éstas ó semejantes palabras: "Aun supuesta la abstención absoluta del Clero en la última contienda, la guerra habría estallado".

El general Mosquera en una hoja que publicó hace poco con el título de "ataque directo á la soberanía de los Estados", y que tenía por objeto impugnar un proyecto de ley, que mandaba establecer universidades en los Estados, dice: "porque él, el proyecto, tiene la tendencia de sojuzgar los espíritus de la juventud á determinados textos en materias políticas y morales, y muy probable á envenenar el alma racional de los jóvenes con doctrinas ateas, materialistas y panteístas, que no dejan de estar en moda en ciertas cabezas vacías, de algunos preceptores ó estudiantes de la universidad de Bogotá [...]

Dios se lo pague al general Mosquera, porque aunque muy tarde ha venido por fin á caer en la cuenta de que el gobierno envenena el alma de la juventud con la enseñanza de doctrinas ateas, materia-

17. RESTREPO, Manuel Canuto, "El clero y el liberalismo en Colombia", Op. Cit., pp. 6-7; 24. 
listas ó panteístas. Luego los Obispos han cumplido su deber rechazando y condenando esas enseñanzas; luego se les ha perseguido y atormentado injustamente $[. . .]^{18}$.

En las siguientes líneas, el obispo Restrepo deja ver su favoritismo por el gobierno de Mariano Ospina Rodríguez (1857-1861), fundador del partido conservador ${ }^{19}$ y artífice de la Constitución de 1843. Escribe una carta constitucional garantista de los intereses de la Iglesia, donde acusa con ahínco el despojo de los tesoros de la Iglesia que hacen los liberales radicales en nombre del progreso y la libertad.

En el año de 1860 presidía los destinos de la nación, [...] Mariano Ospina, tal vez el único presidente legítimo, porque en su elección hubo algo de libertad, es decir, que no vimos los cohechos, fraudes, amenazas, cuchillos, bofetones, palizas y demás privilegios, inmunidades y garantías, que acompañan siempre a la voluntad popular en sus manifestaciones por medio del sufragio libre. Pues bien, entonces que la nación gozaba de completa paz, y marchaba gobernada tan regularmente como era posible, el liberalismo buscó al general Mosquera envejecido en el oficio de verdugo de los liberales, [...]

el liberalismo hizo responsable al Clero de sus propias obras, lo persiguió cruel y bárbaramente en los montes, en

18. Ibíd., pp. 24-26.

19. El matrimonio Iglesia intransigente - Partido conservador fue frecuente durante el siglo XIX, a punto de encontrar posiciones de alienación clerical al partido como por ejemplo Ezequiel Moreno Díaz; sin embargo, había posiciones mesuradas como la del Arzobispo Vicente Arbeláez, quién ante la necesidad de lograr un acercamiento personal con los jefes más importantes del radicalismo y de: "la urgencia de mantener a la Iglesia por encima de los enfrentamientos partidistas evitando la instrumentalización política del clero por parte del Partido Conservador" Véase: GONZÁLEZ GONZÁLEZ, Fernán, "Poderes enfrentados Iglesia y Estado en Colombia", Santafé de Bogotá, Cinep, 1997, p. 201. las cárceles y destierro, mientras que dilapidaba los tesoros de la Iglesia en nombre de la libertad y del progreso, con descrédito de la república y sin provecho alguno para nación.

Parece que Esopo compuso su famosa fábula del lobo y del cordero para representar con ella el liberalismo y el clero de Colombia. El gobierno bebe el agua pura en las alturas de la fuente, pero como necesita un pretexto para devorar al débil corderillo que la toma al lado abajo, lo acusa de ensuciarle el agua, a el pobrecito que tiene la desgracia de beberla turbia y mezclada con la inmunda baba del sangriento rapaz ${ }^{20}$.

Los partidos políticos actúan como máquinas eleccionarias-. Restrepo denunció a los dos partidos como agitadores de revoluciones y poseedores de la máquina eleccionaria; siendo más radical con el liberalismo mira con gratitud al partido conservador aunque le exaspera su quietud y debilidad. En esta materia, si bien critica a los dos partidos, parece olvidar que él mismo fue el organizador del partido católico conservador en el sur del país y fue a través de un partido político que llegó en varias oportunidades al Congreso y a varias legislaturas regionales:

Esos Señores que de un momento á otro se ven levantados, tal vez de la nada á

20. RESTREPO, Manuel Canuto, "El clero y el liberalismo en Colombia”, Óp. Cit., pp. 5-7; Hay que mencionar que la intransigencia y la intolerancia fue mutua entre el Clero y elite liberal. Amplios sectores de la dirigencia liberal radical, convencidos de que las ideas de "libertad" y de "progreso" son incompatibles con el poder del clero, pretendieron, unilateralmente, anular de un plumazo la influencia de la Iglesia, recurriendo, si es necesario a mecanismos coercitivos que lesionan también el sentimiento religioso de muchos colombianos. La mayoría del clero, por su parte, frecuentemente en estrecha alianza con el partido conservador, opone una tenaz resistencia al proyecto de una sociedad "materialista" y ajena a las jerarquías tradicionales, constituyéndose en espacio propicio para la confrontación desde la pluma hasta en el campo de batalla. Amplíese en ARIAS, Ricardo, El episcopado colombiano: intransigencia y laicidad 1850-2000. Bogotá, Uniandes, 2003, p. 32. 
tan alto rango, se creén por lo mismo hecho acreedores á todos los honores y puestos de la nación; comienzan a mover la máquina eleccionaria y á negociar candidaturas para sí mismos, para sus padrinos, compadres y ahijados; y se imponen á los pueblos, no como dictadores de espada, que quizá es arma muy noble para ellos, sino como tiranuelos de bárbaro machete. [...]

A los conservadores tampoco les disgusta la máquina inventada por sus contrarios para improvisar coroneles y generales, aunque á estos tenemos que agradecerles, porque hasta ahora han tenido bastante dignidad personal y respeto á las creencias de la nación, para no ser verdugos de la Iglesia.

Conocíamos el desconcierto, la pereza y la debilidad de un partido, -se refiere al conservador- contrastando lastimosamente con el espíritu de unión, actividad y energía de su competidor; y, por último y sobre todo, veíamos por todas partes hombres civiles y militares saliendo de la máquina donde se improvisan estadistas y guerreros, pero no veíamos en parte alguna un David capaz de conducir con gloria los batallones de Israel al campamento de los gigantes filisteos. Dios sabe que todo esto lo veíamos con bastante claridad, al mismo tiempo que veíamos venir una guerra inevitable encendida por el gobierno ${ }^{21}$.

El Liberalismo es cobarde-. El combativo Canuto no se detiene en la simple adjudicación a los liberales como promotores de guerras, elude cualquier responsabilidad de la Iglesia en estos acontecimientos y al clero lo representa como un estamento débil, perseguido y restaurador, usando esa caracterización para ridiculizar la fuerza desproporcionada de su oponente:

El liberalismo es cobarde, [...] se pavonea orgulloso de su intrepidez y valor, cuando arma batallones para pelear y

21. Ibíd., pp. 18; 31-32. vencer á las monjas: una vez derrotadas toma todos sus despojos y mostrándolos al mundo dice ufano: "ved los portentos de mi valor; este botín es ganado en reñido combate, y es un vuelo en todas las conquistas del progreso." [...]

Para encerrar y coger Obispos y sacerdotes dispersos, pobres y enfermos, que jamás han pensado en atacar á ninguno, ni resistir a nadie, que no tienen más defensa que su mejilla ${ }^{22}$.

Constitución de 1863: idilio poético de libertades en el valle de lágrimas y de miserias que se llama Colombia-. En principio, el deseo de Restrepo era que la carta constitucional de Rionegro "se hubiera muerto en el vientre de sus padres", pero como no fue así, es justo reconocer la habilidad de monseñor para utilizarla a su favor, atacando mordaz y directamente a los liberales radicales. Examina detenidamente la violación de sus derechos y de sus copartidarios mitrados ultramontanos y del clero en general a la luz de la Constitución.

Toma el Artículo 15 de la Constitución, inciso $6^{\circ}$ "La libertad absoluta de imprenta. Inciso $7^{\circ} \mathrm{La}$ libertad de expresar sus pensamientos de palabra o por escrito sin limitación alguna" y argumenta:

Nuestro delito para ser calumniados, perseguidos y desterrados, es ser sacerdotes y Obispos, o haber hablado y escrito para el público: no tenemos otro ante la Constitución y la ley. Ahora bien: si se nos persigue y destierra únicamente por el carácter de que estamos investidos, entonces el liberalismo es enemigo de la Iglesia Católica, y nosotros estamos justificados ante Dios y los hombres de haberlo calificado de tal. Pero esto no puede ser porque los señores liberales lo niegan y aseguran ser tanto o más católicos que los Obispos y el Papa; luego nuestro delito es haber hablado y escrito para

22. Ibíd., p. 36. 
el público en un sentido que no agrada ni conviene al liberalismo: en ambos casos nuestro destierro es inconstitucional, y la retahíla de las garantías se cumple al revés en los Obispos y sacerdotes.

Sí, hemos hablado en la Cátedra y hemos dado nuestros pensamientos a la imprenta, y con esto ihemos violado la Constitución o quebrantado alguna ley ó precepto de la República? No. Muy al contrario, hemos hecho todo eso en fuerza y virtud de la libertad absoluta que para ello nos garantiza la misma Constitución ${ }^{23}$.

Frente a la educación obligatoria promulgada por el gobierno y sarcásticamente llamada por él "corrupción obligatoria", encuentra fundamentos legales que garantizan la libertad de recibir la instrucción" que a bien tenga, defiende la "libertad religiosa de expresión, de palabra, pensamiento y de asociación de su estamento:

El inciso 16 del mismo artículo 15, nos garantiza á todos la libertad religiosa, y sin embargo, el gobierno expide leyes reglamentando nuestra Religión; diciendo bajo qué condiciones debemos observarla y practicarla y quiénes deben ser los ministros de ella. Es como si nos dijera [...] que garantiza á todos la libertad de conciencia, no se entiende con ustedes Obispos y sacerdotes católicos, [...]

El inciso 14 del artículo 15, que garantiza á todos sin excepción la libertad de asociarse sin armas, [...] es una ilusión y una burla para Clero y los católicos y sólo tienen derecho los liberales y las democráticas para asociarse sin armas o con ellas; para pedir la persecución del Clero, el sacrificio de los Obispos y el despojo de la propiedad.

[...] el gobierno ha entendido muy bien el inciso $7^{\circ}$ del artículo 15 respecto de los ministros católicos, porque nos ha dicho: "Con vosotros Obispos y sacerdotes católicos no se entiende la garantía de la palabra y de la imprenta absoluta, á no

23. Ibíd., p. 10. ser que vuestras palabras y pensamientos sean los mios; [...] iQué bella libertad! ${ }^{24}$

Denuncia la inconstitucionalidad de la violación a su domicilio y se jacta de su experiencia y habilidad para escaparse y torear a los liberales calificados despectivamente como "onagros o asnos montés de collar rojo”.

Hablamos y escribimos y nuestras palabras y pensamientos no fueron los del gobierno, ni guardaron armonía con sus ideas, ni agradaron á sus oídos y á su paladar; y entonces sin respetar el inciso 13 del artículo 15 de la Constitución, que garantiza la inviolabilidad del domicilio para no ser allanado, hizo señas á sus esbirros que se componen de la bajeza asalariada, los cuales se lanzaron furiosos sobre nuestras casas, rompiendo puertas y ventanas y despedazando otros objetos, que no les parecieron propios de un botín tomado en buena guerra. No tuvieron la honra y gloria de tomarnos, porque somos peritos en el arte de torear Onagros. Los pollinos del asno montés, de los que se usan ahora, con collar rojo, y pocas horas ántes les habíamos dejado libre el campo, [...] En cuanto á nosotros, salimos de Pasto el día y la hora que nos pareció, después de dos meses $[\ldots]^{25}$

Destierro inconstitucional, violento y cobarde-. Para defenderse de esta medida extrema tomada en su contra y otros prelados intransigentes ${ }^{26}$, cita el inciso

24. Ibíd., pp. 19-20.

25. Ibíd., pp. 20-21.

26. El Congreso de los Estados Unidos de Colombia, mediante la Ley 37 de 12 de mayo de 1877, oficializó el destierro de los obispos intransigentes; Literalmente la norma decreta: Art. $1^{\circ}$. Prohíbese a perpetuidad á los señores Carlos Bermúdez, Manuel Canuto Restrepo, Joaquín Guillermo González y José Ignacio Moncayo, Obispos respectivamente de Popayán, Pasto, Antioquia y Medellín, el ejercicio de funciones de Prelado ú Ordinario eclesiástico en el territorio de los Estados Unidos de Colombia. Art. $2^{\circ}$. Extrañase del territorio de la República á los individuos mencionados en esta ley, por el término de diez años. RESTREPO, Juan Pablo. La Iglesia y el Estado en Colombia, Tomo I, Vol. 132, Bogotá, Biblioteca Banco Popular, 1987. También publicado en: Londres y publicado por Emiliano Isaza, 1885, p. 608. 
$4^{\circ}$ del artículo 15 de la Constitución, que da garantías a los colombianos para: "no ser juzgados por comisiones ó tribunales extraordinarios: ni penados sin ser oídos y vencidos en juicio". A partir de esto hace su acertada disertación:

Supongamos por un momento y en gracia de argumentación, que los Obispos y el Clero fuésemos criminales. ¿Por qué se nos juzga por tribunales extraordinarios y se nos condena á penas gravísimas sin ser ántes oídos y vencidos en juicio? Un congreso que representa la nación y que por lo mismo debe componerse de hombres distinguidos por su ilustración, honradez é imparcialidad para dictar leyes basadas en los eternos principios del derecho, de la razón y de la justicia; ¿puede lanzar penas tan graves como un destierro de diez años á colombianos, sin mas crímen que haber hablado y escrito porque la Constitución de la República se los permite? ${ }^{27}$

Hace remembranza sobre la persecución de obispos y sacerdotes en manos de los liberales radicales condenándolos al sufrimiento y en algunos casos a la muerte:

Muchos son, sí, muchísimos los Obispos que el liberalismo ha oprimido y arrojado sin justicia y sin derecho para ello, del seno de su patria, [...] Que respondan de esta verdad las venerables y sagradas sombras de los Ilmos. y Rmos. Señor Mosquera, Tórres Estans, Herran, Niño, Riaño, Puyana, García Tejada, Arbeláes, Romero y Medina. Algunos, muy pocos, de estos ilustres Obispos tan dignos de las bendiciones de la Iglesia, de la gratitud y admiración de la patria y de la confianza y el amor de los pueblos católicos, $[\ldots]^{28}$

27. RESTREPO, Manuel Canuto. "El clero y el liberalismo en Colombia", Op. Cit., p. 21.

28. Ibíd., p. 8.
Responsabiliza como artífice de su destierro a la Democrática de Cali, cabe recordar que era un momento en dónde el poder asociativo jugó un papel importante en la guerra, por un lado encontrábamos una sociabilidad conservadora principalmente representada por las sociedades católicas y por el lado gubernamental estaban las democráticas como la de Cali, que a juicio de Canuto Restrepo desde sus orígenes -a mediados del siglo y en especial en 1876- protagonizaron la Cruenta toma de la ciudad en una madrugada decembrina, ocasionando pillajes, asesinatos, incendios y la destrucción de viviendas; denunció el ensañamiento del gobierno liberal al perseguirlo por fuera de Colombia e insinuó intentos del gobierno para desaparecerlo:

[...] cuando leímos la memoria pasada por el mismo Sor. Conto, como Presidente, a la legislatura, y vimos en ella que tan bárbara medida fue dictada por complacer a la democracia de Cali [...]

¿Qué cosa es la sociedad democrática de Cali? ¿Cuál es su origen y el número y calidad de sus miembros, y los retosos de su infancia y su historia desde el puñal y el látigo del año 51, hasta el memorable 24 de diciembre de 1876 en Cali...? [...]

El gobierno le dirigió una nota al presidente para que de acuerdo con el ministro Rueda, busquen en todos los puntos de esa república [Ecuador] á dicho Obispo, [...] Una vez entregado lo manda U. por Barbacóas. En Panamá están listas las personas que deben mandarlo al otro continente". ¿Dónde será el otro continente? El pueblo que es buen traductor, por otro continente, á traducido, el otro mundo... ${ }^{29}$.

El Ecuador, país limítrofe con su diócesis va hacer el lugar de su destierro;

29. Ibíd., pp. 12-15. 
ideológicamente este país ya se había declarado como "República del Corazón de Jesús", y a pesar de haber sucedido recientemente el asesinato de García Moreno (agosto de 1875, suceso deplorado por Restrepo en carta pastoral) mantenía acendrado los principios católicos llevados al extremo, además el factor de cercanía le permitió a monseñor Restrepo seguir vigilante de su rebaño a través de pastorales, las cuales fueron prohibidas por las autoridades regionales por considerarlas desestabilizadoras; el inquieto obispo asume la defensa diciendo:

Con respecto á nuestras pastorales, ellas son documentos de carácter público, que todo el mundo ha podido leer. Aun en el caso de que la Constitución de la República no nos diera pleno derecho é ilimitada libertad para hablar y escribir, no se nos podría con justicia perseguir y castigar por ellas, puesto que nada contienen contrario á la moral ni á la Constitución del país. Por el contrario, todo lo que ellas contienen es justo, decente y estrictamente Constitucional. En ellas hemos aconsejado á los pueblos el uso de la imprenta, la lectura de buenos libros y periódicos, la enseñanza cristiana de la niñez, la instrucción religiosa del pueblo, la práctica del derecho de sufragio en las elecciones, la asociación sin armas; el recurso de petición á las autoridades y corporación públicas; y en último caso, la resistencia pasiva, $[\ldots]^{30}$

Con lenguaje sardónico pone en duda el poder de la palabra emanada por el clero para formar batallones en contra de los liberales, y demostrando su erudición clásica retoma ejemplos comparándose con reconocidos oradores de la antigüedad:

[...] ¿Con que nuestra palabra los hace desfilar lenta y sucesivamente en formidables batallones, como siguen unas

30. Ibíd., p. 28. á otras las olas de un mar agitado? No teníamos noticia hasta hoy, que nos la dan los SS. Liberales, de las maravillas que sabe hacer la mágia secreta que posée el clero de Colombia, é ignorábamos por completo los portentos de su palabra $[\ldots]$

Si SS. Liberales, no queráis dar á nuestra palabra, con mengua vuestra, aquel poder misterioso que tenía la del Apóstol de las naciones, á quien llamaba San Jerónimo, la trompeta del evangelio, el rugido del león, y el trueno de los pueblos. No queráis darnos aquella elocuencia dulce y encantadora con que San Juan Crisóstomo conmovia é inflamaba al pueblo de Constantinopla [...] no queráis darnos un puesto en el foro romano entre Ciserón y Hortencio, ni colocarnos en Atenas al lado de Demóstenes, ni haceros pulsar la lira de Tirteo al frente de los batallones de Esparta $[\ldots]^{31}$.

El obispo Manuel Canuto, consciente de su poder y liderazgo para generar oposición al gobierno de los radicales caucanos, se "honra" por el miedo que les genera:

¡Qué vergüenza para el tal gobierno del Cauca! A un Obispo enfermo, pobre y proscrito léjos de su hogar y de su patria, le tienen los liberales más miedo, que el que tenían los romanos al viejo Aníbal desterrado. Todos nuestros padecimientos físicos y nuestras penas morales, quedan mas que suficientemente compensado con tal alta honra ${ }^{32}$.

La contienda entre la Laicidad y el Catolicismo Intransigente, ocupa un lugar central para la época; en esta parte, la Laicidad, en el caso colombiano se ha reducido como la simple separación de poderes, tendiente a limitar el poder

31. Ibíd., pp. 34-35.

32. Ibíd., p. 40. 
religioso y su influencia social ${ }^{33}$, sin embargo, Ricardo Arias, siguiendo trabajos de investigadores franceses especialmente a Émile Poulat expresa: la laicidad "representa el ideal, modesto pero exigente, de una sociedad dividida en la que nadie puede pretender convertir sus convicciones en leyes y en la que correlativamente, nadie puede ser excluido por sus convicciones". El autor francés insiste -dice Arias- en la construcción de un espacio público en el que debe primar la libertad de conciencia, máxima expresión del carácter revolucionario de la laicidad. No se trata de sustituir el régimen confesional por la verdad de cada individuo, sino por el acceso a una sociedad abierta de la que nadie puede ser excluido; retomando a Poulat, concluye: "...la laicidad, antes que todo [...], es el fortalecimiento de la conciencia y de su libertad [...]. La laicidad no es el triunfo del Estado sobre la Iglesia en torno al control de las conciencias. Es [...] una reconstrucción [refondation] de la sociedad a través del reconocimiento a todos de un derecho natural a la libertad pública de conciencia" 34 . Si aplicáramos estas consideraciones teóricas para la época observaríamos que lo que menos se dio fue la garantía de libertad pública de conciencia pese a que el marco legal de 1863 lo contemplaba y en esto tenía razón el prelado Restrepo, en sus vehementes reclamos por ser víctima de persecución y destierro.

Haciendo un breve análisis del lenguaje utilizado en la obra: El clero y el liberalismo en Colombia del obispo Restrepo, se observa que para caracterizar a los dos estamentos utiliza una

33. ARIAS, Ricardo, Estado laico y catolicismo integral en Colombia. La reforma religiosa de López Pumarejo, [Online], [consultado 10 octubre de 2013]. Disponible en dialnet.unirioja.es/servlet/ articulo? codigo $=2186776$, p. 71 .

34. ARIAS, Ricardo, El episcopado colombiano: intransigencia y laicidad 1850-2000. Op. Cit., p. 46 polarización que se muestra en blanco y negro, mundos binarios ${ }^{35}$, que dada la ortodoxia de su autor terminó santificando al clero y satanizando a los liberales. Para referirse al clero son frecuentes los calificativos como: Clero abnegado, representado como débil corderillo, la misión que adelanta es restituir la nación, la paz; defensor de principios de verdady de justicia, y siempre víctimas de los atropellos de los liberales; en contraposición, para describir a los liberales se utiliza terminología fuerte como: ambiciosos vulgares, tiranuelos de bárbaro machete, reos de lesa patria, gobierno impío, bárbaros salvajes, gigantes sin cabeza, paganos, cobardes, ridículos, verdugos, bestias, déspotas republicanos, tiranos, lobos, títeres de las sociedades democráticas, escorias soberanos, sangrientos rapaces...

Finalmente, el desterrado obispo Restrepo, parafraseando a César Cantú, expresa: "de que a pesar del odio y persecución del liberalismo al Clero, siempre quedará un Sacerdote Católico que, postrado junto al sepulcro del último liberal, ore por su alma y pronuncie sobre sus cenizas el Requiescat in pace de la eternidad" 36 . El obispo Restrepo fue visionario en esta apreciación ya que se acercaba el fin de los liberales radicales.

35. La interpretación de una visión maniquea del mundo, fue frecuente del catolicismo intransigente argumentando que, existe un polo opuesto al catolicismo. Se presenta el enfrentamiento revolución versus catolicismo, el bien contra el mal, cielo contra infierno, ateo versus creyente, sin posibilidad de entablar ningún diálogo; justifica la visión pesimista del hombre, que consiste en mostrar a la especie humana como inclinada naturalmente hacia el mal; defendiendo la enseñanza católica como la única posible e integral, como la única verdadera; negando toda posibilidad al error, [el liberalismo] ya que la verdad es la única con derechos, y ésta se encuentra sólo en el catolicismo. CORTÉS GUERRERO, José David. Curas y políticos: mentalidad religiosa e intransigencia en la diócesis de Tunja, Op. Cit., p. 42.

36. RESTREPO, Manuel Canuto, "El clero y el liberalismo en Colombia", Op. Cit., p. 38. 


\section{BIBLIOGRAFÍA}

ARIAS, Ricardo. El episcopado colombiano: intransigencia y laicidad 1850-2000. Bogotá, Uniandes, 2003.

ARIAS, Ricardo. Estado laico y catolicismo integral en Colombia. La reforma religiosa de López Pumarejo, [Online], [consultado 10 octubre de 2013]. Disponible en dialnet.unirioja.es/servlet/articulo?codigo=2186776

CORTÉS GUERRERO, José David. Curas y políticos: mentalidad religiosa e intransigencia en la diócesis de Tunja, Bogotá, Ministerio de Cultura, 1998.

DI STEFANO, Roberto, “El púlpito y la plaza: clero, sociedad y política de la monarquía católica a la república rosista" primera edición, Buenos Aires, Siglo XXI Editores Argentina, 2004, p.127

GONZÁLEZ GONZÁLEZ, Fernán. “Poderes enfrentados Iglesia y Estado en Colombia”, Santafé de Bogotá, Cinep, 1997.

LOAIZA CANO, Gilberto. Sociabilidad, religión y política en la definición de la Nación, Colombia 1820-1886, Bogotá, Universidad Externado de Colombia.

LONDOÑO VEGA, Patricia. Religión, cultura y sociedad en Colombia, Medellín y Antioquía, 1850-1930, Bogotá, Fondo de Cultura Económica, 2004.

MARTÍNEZ DE CODES, Rosa María. La Iglesia Católica en la América Independiente, Madrid, (Siglo XIX). Editorial Mapfre, 1992.

MORALES BENITTEZ, Otto. Trascendencia, dimensión y proyección de las historias regionales y locales, México, Universidad Nacional Autónoma de México, 1993. p. 37.

ORTIZ MESA, Luis Javier. “Obispos, clérigos y fieles en pie de guerra Antioquía, 1870-1880”.

PLATA QUEZADA, William. “La romanización de la Iglesia en el siglo XIX, proyecto globalizador del tradicionalismo católico" contenido en: Globalización y diversidad religiosa en Colombia, Bogotá, Unibiblos, 2005 [Online] [Consultado 01 de octubre de 2013]. Disponible en http://www.bdigital.unal.edu.co/1390/4/03CAPI02.pdf

RESTREPO, Juan Pablo. La Iglesia y el Estado en Colombia, Tomo I, Vol. 132, Bogotá, Biblioteca Banco Popular, 1987. También publicado en: Londres y publicado por Emiliano Isaza, 1885, p. 608.

RESTREPO, Manuel Canuto. “El clero y el liberalismo en Colombia”, Folleto, Ecuador, Julio de 1878, texto ubicado en la Biblioteca Museo Juan Lorenzo Lucero de Pasto. 